\title{
“Ethical, ooh, Yeah Ethical is Yeah, What's Right Yeah”': A Snapshot of First Year Law Student's Conception of Ethics
}

\author{
Kieran Tranter ${ }^{\#}$
}

\section{Abstract}

This research develops a baseline conception of ethics of first year law students. The research is grounded on the awareness that the call for greater ethical conduct within the profession is based on a particularly strong conception of ethics; namely ethics deals with the public accountability to the Good for the practical values and judgments an individual makes in their daily life. The research uncovered that law students did not share this conception of ethics. Students tended to either reduce the ethical to another field of human conduct, such as politics or law, or conceived it as the realm of subjective morality that involved no public accountability. This vacuity of ethics for first year law students presents an added challenge to the ethical legal education

\footnotetext{
${ }^{1}$ Participant L, Female, 17-19.

\# Lecturer, Socio-Legal Research Centre, Griffith University. This research was funded by an Australian Research Council small grant while I was a Lecturer and Social Justice Coordinator at the University of Notre Dame Australia. I would like to thank Associate Professor Mary McComish (University of Notre Dame Australia) and Associate Professor Michael Robertson (Griffith University) for help in clarifying this project. I would also like to thank Lyndal Sleep (Edith Cowan University) for assistance in developing the research strategy and in analysing the data. Finally, I would like to thank Amanda Sapienza for conducting and transcribing the interviews.
} 
project in that before ethics can be taught, ethics must be made to mean something.

\section{Introduction}

This research examines the baseline conception of ethics of students beginning legal education through a qualitative analysis of responses to a series of open-ended questions. It found that the students had a poor understanding of ethics as a distinct way of thinking about values and judgments. Instead, ethics was either treated as a vacuous concept that was substantiated by other standards, such as law, or was regarded as morality characterised by subjectivity and private accountability. These findings present a significant challenge to the project of ethical legal education. It suggests that the task of ethical education is not just to teach certain modes of ethical conduct or professional responsibility, but also to establish the ethical as a distinct and valuable standard for the discussion and evaluation of human action.

\section{Background to Research: Ethics, Legal Ethics and Ethical Legal Education}

\section{Introduction}

The context for this research is the project of providing ethical education to law students. The research is based in two discourses. The first is the discourse behind the ethical legal education project - the call for a more ethical legal profession. The 
second is the evaluation side of the ethical legal education project and how to gauge the effectiveness of strategies that attempt to ‘teach’ ethics to students.

\section{The Call for Legal Ethics}

A primary reason legal educators concern themselves with teaching ethics is a longstanding critique of the way that lawyers act. $^{2}$ This critique identifies declining standards of professional conduct on the part of lawyers and sees in this decline the declining public profile of the profession. ${ }^{3}$ Many have observed that the public regards lawyers as self-seeking manipulators far more concerned with winning at all cost for wealthy clients then ensuring justice and integrity in the legal system. ${ }^{4}$ The common prognosis of this disillusionment is a growing cynicism with the law and the

\footnotetext{
${ }^{2}$ K Economides “Legal Ethics - Three Challenges for the Next Millennium” in K Economides (ed),
} Ethical Challenges to Legal Education and Conduct (Oxford, Hart Publishing, 1998) p. xx.

${ }^{3}$ M Kirby “Legal Professional Ethics in a Time of Change” (1996) 14 Australian Bar Review 170 at 180.

${ }^{4}$ Kirby identifies that a significant voice for this critique in the United States was Anthony Kronman in A Kronman The Lost Lawyer: Failing Ideals of the Legal Profession (Cambridge MA, Harvard University Press, 1993) and the theme was taken up strongly in Australia by D Dawson “The Legal Service Market” (1996) 5 Journal of Judicial Administration 147. See Kirby, supra [n. 3], pp. 172-173. To argue a decline in the profession is to assume that in the past the profession was nobler and less commercially orientated. Recent historical analysis of the profession renders this assumption problematic. R McQueen “Together We Fall, Divided We Stand: The Victorian Legal Profession in Crisis 1890-1940” in W Pue and D Sugarman (eds), Lawyers and Vampires: Cultural Histories of the Legal Professions (Oxford, Hart Publishing, 2003) pp. 293-328. 
legal system ${ }^{5}$ and a general unhappiness and pessimism in lawyers themselves. ${ }^{6}$ The diagnosis is the call for a reinvigoration and a taking seriously the ethical dimensions of practice. $^{7}$

Inherent in this trumpeting of ethics is a particularly strong conception of ethics; namely that ethics deals with the public accountability to the Good for the practical values and judgments an individual makes in their daily life. This conception of ethics is at odds with the traditional conception of legal ethics as the formal codes of practice. ${ }^{8}$ Also, at first blush this definition of ethics seems at odds with the ethics discussed in what can be called the 'advocate literature,' that is the repeated calls from judges, academics and senior lawyers for a more ethical profession. In the 'advocate literature' ethics is rarely defined so precisely, instead the call for ethics is located within a perceived need to go beyond codes to changing the 'mind-set" ${ }^{9}$ or 'culture' of practice. ${ }^{10}$ In doing so ethics is left prima facie unsubstantiated. However, implicit in talk of changing mind-sets or culture is an enterprise involving changing the values and judgments of lawyers. For legal thinkers this is murky and amorphous

\footnotetext{
${ }^{5}$ C Sampford and S Blencowe “Education Lawyers to be Ethical Advisors” in K Economides (ed), Ethical Challenges to Legal Education and Conduct (Oxford, Hart Publishing, 1998) p. 316.

${ }^{6}$ M Seligman, P Verkuil, T Kang “Why Lawyers are Unhappy” (2001) 23 Cardozo Law Review 33.

${ }^{7}$ D Luban and M Millemann “Good Judgement; Ethics Teaching in Dark Times” (1995) 9 Georgetown Journal of Legal Ethics 31 at 36.

${ }^{8}$ G Dal Pont Lawyers’ Professional Responsibility in Australia and New Zealand $2{ }^{\text {nd }}$ ed (Pyrmont, LBC, 2001) p. 3.

${ }^{9}$ G Davies "Fairness in a Predominantly Adversarial System” in H Stacy and M Lavarch (eds), Beyond the Adversarial System (Sydney, Federation Press, 1999).

${ }^{10}$ P Schiltz "Legal Ethics in Decline: The Elite Law Firm, the Elite Law School, and the Moral Formation of the Novice Attorney” (1999) 82 Minnesota Law Review 705.
} 
because it seems to involve dealing not with the objective realm of legal rules, but the subjective realm of the personal. ${ }^{11}$ Therefore, many within the advocate literature shy away from directly delineating the ethics that they regard as the panacea for the malaise of practice. $^{12}$

This is a problem for legal educators attempting to teach for ethical lawyers because knowledge precedes teaching. While it is well and good to document a decline in the standards of lawyering and suggest ethics as the solution, such an approach cannot instruct students on how to be the desired ethical lawyers. ${ }^{13}$ To teach legal ethics greater knowledge of the ethical is required. What exactly is meant as legal ethics within the advocate literature requires excavation. In order to facilitate this uncovering an understanding why there is reluctance by lawyers to directly talk about the ethical is required.

The reluctance stems from the lingering positivism within legal thought. Positivism attempted a strong line between the real, the public and the objective, and the insubstantial, the private and subjective. ${ }^{14}$ Its enduring legacy has been the delineation between the objective law of a society and the commands, orders, threats, conventions

\footnotetext{
${ }^{11}$ V Olgiati “Can Legal Ethics Become a Matter of Academic Teaching? Critical Observations from a Late-Modern Perspective” in K Economides (ed), Ethical Challenges to Legal Education and Conduct (Oxford, Hart Publishing, 1998) p. 84.

12 J Webb “Being a Lawyer/ Being a Human Being” (2002) 5Legal Ethics 130 at 132.

${ }^{13}$ C Sampford with C Parker “Legal Regulation, Ethical Standard-Setting and Institutional Design” in S Parker and C Sampford (eds), Legal Ethics and Legal Practice: Contemporary Issues (Oxford, Clarendon Press, 1995) p. 15.

${ }^{14}$ R Dworkin Taking Rights Seriously (London, Duckworth, 1977) p. 17.
} 
and social pressures, in short all the other imperatives on human action, that are to be excluded from the study of law properly called. ${ }^{15}$ In trying to carve an unique science of jurisprudence and a discrete practice of law, the remainder, the imperatives that failed to satisfy the positivists' concrete definition of law, were compressed and devalued as subjectivities. Politics, ethics and morality became characterised by the subjective will: They were realms in which the individual was free to choose their values and actions. ${ }^{16}$ The question of accountability for action in such a posited universe became legalised. Law provided objective right (lawful) and wrong (unlawful) distinctions, while the reminding imperatives were characterised by indecision, sophistry and irresolvable value conflict.

While the death of positivism has been widely announced in philosophical ${ }^{17}$ and jurisprudential circles, ${ }^{18}$ its influence can be strongly detected in the call for legal ethics. The reason that ethics is not directly addressed in much of the advocate literature is that many advocates tacitly accept the key positivist thesis - that ethics is really a private question involving messy judgments about personal values. Alan Hutchinson in his recent text on legal ethics presents the thesis that:

To be an ethical lawyer involves more than learning and applying a set of rules; it also demands the cultivation of a critical reflection on the professional role and responsibilities of lawyers. In short, a fully ethical

\footnotetext{
${ }^{15}$ J Austin The Province of Jurisprudence Determined $3^{\text {rd }}$ ed (London, John Murray, 1869) pp. 88-106.

${ }^{16}$ A MacIntyre After Virtue $2^{\text {nd }}$ ed (Indiana, University of Notre Dame Press, 1984) p. 12.

${ }^{17}$ W Barrett Irrational Man: A Study in Existential Philosophy (New York, Doubleday Anchor, 1958) pp. 26-40.
}

${ }^{18}$ M Davies Asking the Law Question $2^{\text {nd }}$ Ed (Pyrmont, LBC, 2002) p.104. 
practice requires an independent sense of moral virtue that involves the lifelong development of personal moral character. ${ }^{19}$

Hutchinson justifies his stance with reference to Isaiah Berlin's perspective that human nature is such that values conflict and therefore the rational individual must live a life of choice. ${ }^{20}$ Hutchinson seems to be suggesting that ethics is a subjective personal event and as such the content of ethics is a matter of personal reflection and development. He can be seen as respecting the barrier of the personal for he does not articulate the values of a 'morally virtuous' lawyer. Instead, he emphases the need for reflective judgment, yet the values and process of that judgment remain undisclosed.

This shying away from directly talking and evaluating values and judgments is a feature of much of the advocate literature. However, it is merely a surface concession to positivism. Advocates call for ethics instrumentally. They want ethics to change legal cultures; how lawyers act, what they value and the judgments that they make. ${ }^{21}$ To do so is to claim a much more substantive content for the ethical then a subjective realm of value choices. This called for ethics involves a public element, a notion of external standards to which an individual is called to account. Consequently, this submerged ethics lies closer to the classical, pre-positivist conception of the ethical.

\footnotetext{
${ }^{19}$ A Hutchinson Legal Ethics and Professional Responsibility (Toronto, Irwin Law, 1999) p. 47.

${ }^{20}$ I Berlin Four Essays on Liberty (Oxford, Oxford University Press, 1969) p. li.

${ }^{21}$ A Goldsmith and G Powles “Lawyers Behaving Badly: Where Now in Legal Education for Acting Responsibly in Australia?” in K Economides (ed), Ethical Challenges to Legal Education and Conduct (Oxford, Hart Publishing, 1998) p. 143.
} 
The classical starting point for ethics is Aristotle's emphasis that ethics is a practical discipline - in that it is concern with how human action in the actual world of everyday existence measures up to the Good. ${ }^{22}$ As such the ethical deals with how a person navigates the daily interactions of life. It is concerned with the values and the judgments made, not just in large choices, but also in the multitude of small-scale decisions of everyday existence. ${ }^{23}$ As such the focus of ethics is the self but it is not the degraded realm of subjectivity as the positivists suggest, for the classical scope of ethics concerns evaluation of the Good of such action. ${ }^{24}$ Notwithstanding his emphasis on the personal Hutchinson does recognises this, “...lawyers must be prepared to answer for the ethical choices they make and the legal practice in which they engage. Simply pointing to some rule is never enough on its own." ${ }^{25}$ Here Hutchinson uncovers another key dimension of the ethical - that it is a place of accountability, not just to the self, but analogous and parallel to the public accountability of the legal. From these threads the scope of ethics can be derived: Ethics deals with the public accountability to the Good for the practical values and judgments an individual makes in their daily life.

This delineation of the ethical is exactly the conception of ethics that underpins the advocate literature desire for ethics to change legal culture. The advocate literature claims that the focus of ethics is the individual but that the values and judgments an individual makes are not hidden behind a non-justiciable private divide. Instead, the

\footnotetext{
${ }^{22}$ Aristotle The Nicomachean Ethics (trans J Thomson) (London, Penguin Books, 1953) pp. 64-64 [1094a-1094b].

${ }^{23}$ Luban and Millemann supra [n. 7], pp. 58-64.

${ }^{24}$ J Finnis Fundamentals of Ethics (Washington, Georgetown University Press, 1983) p 4.

${ }^{25}$ Hutchinson supra [n. 19], p. 56.
} 
individual should be held accountable to the wider conception of the Good for their actions; that the values and judgements that lawyers make are properly the subject of justification and scrutiny to some external criteria such as society or professionalism.

In articulating this embedded concept of ethics sharper distinctions can be drawn between the ethical and other imperatives on human action. These distinctions are not the sharp distinctions of positivism but are relational and non-exclusive. Figure 1 sets out the relations between politics, law, morality and ethics.

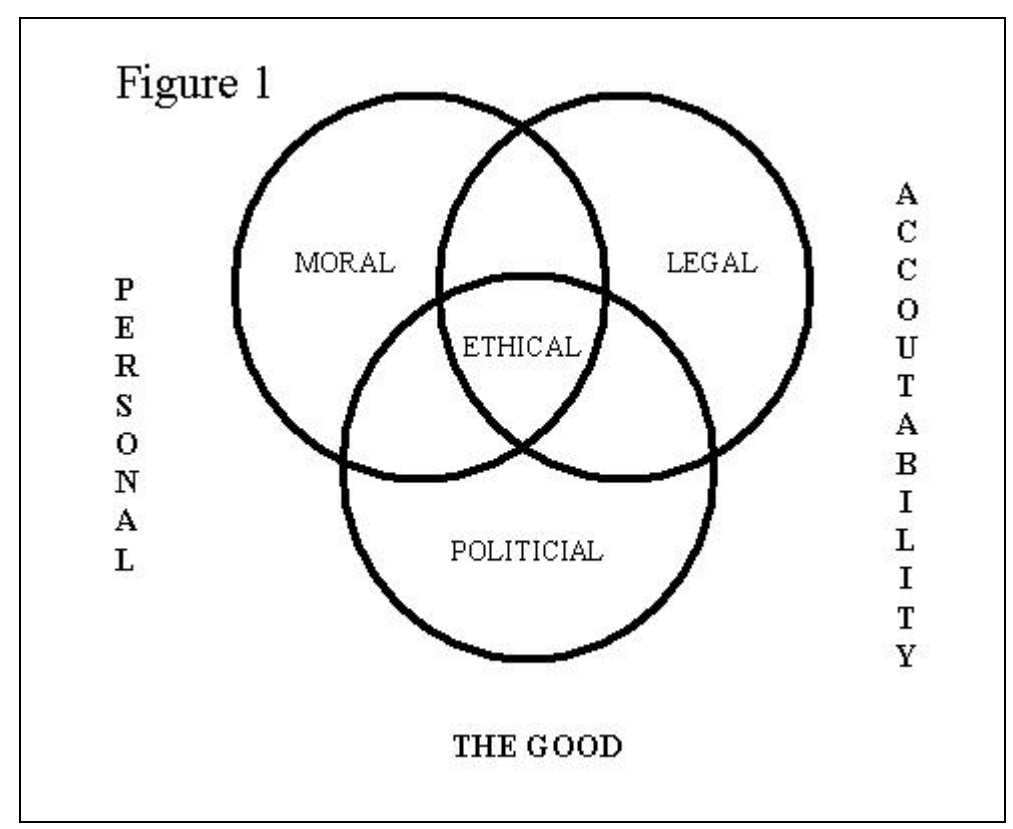

From figure 1 it can be seen that ethics shares with law the key characteristic of accountability for actions. The distinction between law and ethics is the type and intensity of sanction imposed. The classical concern in legal ethics that certain behaviour might be legal yet be unethical witnesses this distinction. ${ }^{26}$ Similarly, ethics

\footnotetext{
${ }^{26}$ Dal Pont supra [n. 8], p. 14.
} 
shares with politics a concern with the Good, but is distinguishable from politics, in that politics involves the thinking about institutional or social change, but does not have as its focus the individual self. As such it is possible to be unethical while engaging in politically justified legal practice. ${ }^{27}$ Likewise, ethics shares with morality a focus on the values and judgments of an individual. Yet where morality suggests that values and judgments are subjective and personal, ethics involves accountability for values and judgments made. In the words of Thomas Shaffer "Ethics is thinking about morals and, beyond that, explaining one's thought to others...It is about explaining one's reaction to a moral impulse and listening to the reactions of others."28

The forgoing analysis has clarified the underlying conception of ethics that informs the call for a more ethical legal profession. In doing so not only is the scope of the ethical delineated, but the ethical is situated in relation to other fields for the thinking about human action. It is this conception of the ethical as the public accountability to the Good for the practical values and judgments an individual makes in their daily life that was the subject of this research.

\section{Ethical Legal Education}

\footnotetext{
${ }^{27}$ L White "Subordination, Rhetorical Survival Skills and Sunday Shoes: Notes on the Hearing of Mrs G” in M Fineman and N Thomadsen (eds), At the Boundaries of Law: Feminism and Legal Theory (New York, Routledge, 1991) pp. 42-58.

${ }^{28}$ T Shaffer “On Tending to the Ethics in Legal Ethics: Two Pedagogical Experiments” (2001) 12 Legal Education Review 11 at 15.
} 
The literature concerning ethical legal education is particularly characterised by the method question; what is the right way to teach ethics? ${ }^{29}$ There are three positions. The first is clinical legal education (CLE). Supporters of CLE claim that in exposing students to 'real life' legal practice and 'real live' lawyers, CLE, provides concrete examples of ethical dilemmas that face lawyers and provides the monitoring and role models for students to think through these dilemmas. ${ }^{30}$ The second is to infuse ethics within the orthodox subjects of the law curriculum. ${ }^{31}$ In this way ethics is treated similar to practical legal skills both of which should be 'built' into subject material and assessment. ${ }^{32}$ The third way is to bolster the legal ethics component of final year professional practice subjects or offer discrete subjects in legal ethics. The purpose of this approach is to ensure students not only have a strong knowledge of the professional codes but understanding of the spirit of ethical practice to inform decisions in the 'hard cases' of ambiguous ethical conduct.

This research is not primarily concerned with which approach - clinics, pervasive ethics, discrete subjects - is the better way to teach ethics to law students. Although, one of the findings suggest that experiential learning is significant in developing an

\footnotetext{
${ }^{29}$ D Rhode “Into the Valley of Ethics: Professional Responsibility and Educational Reform” (1995) 58 Law and Contemporary Problems 139, B Brooks “Ethics and Legal Education” (1998) 28 Victorian University of Wellington Law Review 157 at 163, S Burns “Teaching Legal Ethics” (1993) 4 Legal Education Review 142.

${ }^{30}$ A Evans “The Values Priority in Quality Legal Education: Developing a Values-Skills Link through Clinical Experiences” (1998) 32 The Law Teacher 274 at 283-284 and Luban and Millemann supra [n. 7], pp. 31-87.

${ }^{31}$ D Rhode "Ethics by the Pervasive Method," (1992) 42Journal of Legal Education 31.
} 
appreciation of the ethical. Instead, this research is directed towards the evaluation of the effectiveness of teaching strategies through examining the baseline conception of ethics of students entering law school. As the project of ethical legal education is now well established $^{33}$ a fundamental question arises: Whether anything that happens in law school is capable of changing the values and judgments of law students? This is an empirical question and any response requires a baseline insight into the pre-law school ethics of law students. Knowing the baseline ethics has a secondary benefit for legal educators. Knowledge of the baseline ethics should help legal educators refine and target more precisely ethical legal education strategies.

\section{Past Research into the Ethics of Lawyers and Law Students}

There has been little research into the conception of ethics of lawyers and law students in Australia. ${ }^{34}$ Two recent projects that attempt to address this lack of

\footnotetext{
${ }^{32}$ J Webb “Developing Ethical Lawyers: Can Legal Education Enhance Access to Justice?” (1999) 33
} Law Teacher 284 at 293.

${ }^{33}$ F Armer "The Teaching of Ethics in Australian Law Schools" (1998) 16 Journal of Professional Legal Education 247.

${ }^{34}$ Debra Lamb has undertaken research eliciting the types of ethical dilemmas that Australian lawyers face, however her research does not examine in detail the values and process of judgment that lawyers actually make. See D Lamb “Ethical Dilemmas: What Australian Lawyers Say About Them” in S Parker and C Sampford (eds), Legal Ethics and Legal Practice: Contemporary Issues (Oxford, Clarendon Press, 1995) pp. 217-234. June Chapman documents the findings of several studies on the effect of legal education on student ethics in both the United States and England. J Chapman "Why Teach Legal Ethics to Undergraduates?” (2002) 5 Legal Ethics 68 at 73-79. 
empirical knowledge are Evans’ Values survey of Australian lawyers ${ }^{35}$ and Parker’s detailed review of student feedback in the "Law, Lawyers and Society" course at the University of New South Wales. ${ }^{36}$ Evans has now published two results from his Values survey. The first results were from his pilot study of graduates from Monash University. The second results are the interim first year findings from his national survey of the law graduating class of 2001. Evans disputes the folk-wisdom of some that ultimately members of the law profession share a common pool of values. ${ }^{37}$ Instead, his pilot study, and the interim results found that the values of the Monash graduates and the graduating class of 2001 were markedly divided on corporate and justice grounds, and according to gender. ${ }^{38}$ Evans' research begins the task of documenting the actual values of Australian lawyers. ${ }^{39}$ Aside from some correlation that graduates who undertook CLE had a higher commitment to justice values, ${ }^{40}$ Evans does not look at the formation of values prior to or during legal education. The

\footnotetext{
${ }^{35}$ A Evans “Lawyers' Perceptions of their Values: an Empirical Assessment of Monash University Graduates in Law, 1980-1998” (2001) 12 Legal Education Review 209.

${ }^{36}$ C Parker “What Do They Learn When They Learn Legal Ethics?” (2001) 12 Legal Education Review 175.

${ }^{37}$ A Evans and J Palermo “Australian Law Students’ Perception of their Values; Interim Results in the First Year - 2001 - of a Three-Year Empirical Assessment” (2002) 5 Legal Ethics 103 at 105.

${ }^{38}$ Ibid., p. 128 and Evans supra [n. 35], pp. 260-261

${ }^{39}$ Evans talks about values instead of ethics because:
}

Values are said to underlie our behaviour and are assumed to have great influence: but they are rarely discussed...Ethics while also intending to govern behaviour, have been discussed ad nauseam to the point that they are now regrettably confused with specific rules of conduct.

Evans supra [n. 30], pp. 280-281.

${ }^{40}$ Evans supra [n. 35], pp. 242-243. 
express aim of the National Values Survey is to document the development or degradation of lawyers' values over time. ${ }^{41}$ Evans' findings raise an important question; what influences contributed to the graduates' values?

Parker's review of student feedback at the University of New South Wales exposes the wins and losses involved in teaching a compulsory final year legal ethics course. A significant theme in Parker's review is cynicism. ${ }^{42}$ She finds what others have reported anecdotally that teachers of legal ethics to final year students face a harsh classroom environment marked by student cynicism. ${ }^{43}$ Parker suggests that the law school context itself might be the cause of this cynicism, "many law students come to the legal ethics course already believing that all law subjects are about learning the rules and how to cleverly manipulate them." ${ }^{44}$ Parker seems to be subscribing to an establish critique of legal education - that the law school experience itself generates cynical and opportunistic egotists. ${ }^{45}$ Embedded in this critique is a belief that students entering law school are genuine, nice and ethical. While Parker looks at the ethics and the battle of ethical legal education in the final years of the curriculum, she does not examine the ethical baseline of students entering legal education.

\footnotetext{
${ }^{41}$ Evans and Palermo supra [n. 37], p. 103.

${ }^{42}$ Parker supra [n. 36], pp. 182, 186.

${ }^{43}$ D Frenkel “On Trying to Teach Judgment” (2001) 12 Legal Education Review 19 at 23.

${ }^{44}$ Parker supra [n. 36], 183.

${ }^{45}$ Famously articulated by Duncan Kennedy in D Kennedy “Legal Education as Training for

Hierarchy” in D Kairys (ed), The Politics of Law: A Progressive Critique (New York, Patheon Books, 1990).
} 
This current research supplements Evans' and Parker's research by canvassing the values and judgments of students entering legal education with the aim of contributing to a baseline understanding of student's conception of ethics.

\section{Context and Method of Current Research}

This research was undertaken on a sample of first year law students at the College of Law, University of Notre Dame Australia. As a Catholic law school, the College of Law has an express commitment to ethical legal education. ${ }^{46}$ This commitment was manifested in the curriculum in a variety of ways. First, the College had a commitment to pervasive ethical education, with each substantive core subject having an ethical component. ${ }^{47}$ Second, the curriculum included compulsory subjects in legal ethics, in professional practice ${ }^{48}$ and offered a CLE elective for final year students. ${ }^{49}$ Third, all law students had to undertake three university wide foundational units in ethics, philosophy and theology. Finally, drawing upon the North American Catholic education tradition of 'service learning' the College had a mandatory requirement for students to undertake unpaid service work in the community. ${ }^{50}$ The current research

\footnotetext{
${ }^{46}$ G Craven "Foreword by the Dean” (1999) 1 University of Notre Dame Australia Law Review ix. On the imperative to education the ethical for a Catholic Law Schools see R Araujo "Legal Education and Jesuit Universities: Mission ands Ministry of the Society of Jesus” (1991) 37 Loyola Law Review 245 at 250 .

${ }^{47}$ Armer supra [n. 33], p. 253.

${ }^{48}$ For a review of one of the professional practice subjects see C Hammond "Teaching Practical Legal Problem Solving Skills: Preparing Law Students for the Realities of Legal Life” (1999) 10 Legal

Education Review 191.

${ }^{49}$ K Tranter and L Jarvis “Clinical Legal Education in a Catholic Law School” (2000) 27 Brief 24.

${ }^{50}$ K Tranter “Pro-Bono Ethos: Teaching Legal Ethics” (2002) 29 Brief 12.
} 
grew out of this heavy commitment to ethical education and value change as part of the needed reflection on the effectiveness of these strategies.

All the students interviewed where enrolled in the foundation year ethics subject. ${ }^{51}$ The interviews were conducted over the first few weeks of the semester. Fourteen students were interviewed, representing a sample of 32\% of the students enrolled in the subject. There was an equal split of seven male and seven female participants. The age split reflected a preponderance of school leavers. Table 1 sets out the ages within the sample.

Table 1: Ages Participants

\begin{tabular}{|c|c|c|c|c|}
\hline 17-19 & 20-22 & 23-25 & 26-30 & 31-35 \\
\hline 9 & 2 & 1 & 0 & 1 \\
\hline
\end{tabular}

The interviews comprised eliciting responses to a series of open-ended questions. Open-ended questioning allowed both the participant and interviewer to explore trains of thought beyond the set questions. The interviewer was given freedom to devise follow-up questions and depart from the interview schedule in the interests of getting a fuller account from the participant. Thus, open-ended questions were useful for

\footnotetext{
${ }^{51}$ For another attempt to teach ethics to first year students see D Henriss-Anderssen “Teaching Legal Ethics to First Year Law Students” 13 Legal Education Review 45.
} 
gathering the participant's own conception of ethics and express their values and judgments in their own words. ${ }^{52}$

The interview was divided into four sections. Section one was designed to gather an overview of the participant's concepts of ethics. It was also designed to make the participant relax and become comfortable with talking to the interviewer. Section two involved participants responding to three distinct ethical dilemmas that face legal practitioners. ${ }^{53}$ Section three involved asking the participants to reflect on their own ethical development and articulate what factors or experiences had formed their ethics. The final section elicited demographic information. The interview plan is set out in the appendix.

A final year law student with a strong interest in ethics and legal professionalism was trained to undertake the interviews. The use of an older year student was for two reasons. First, by having the interviewer as a law student and much closer in age to the participants it was hoped to produce a relaxed interviewing environment in which the participants felt comfortable talking about personal matters. This was desirable because the open-ended questions in the interview schedule would elicit the most information if the interview could best replicate peer-to-peer discussions. Second, as the principal researcher was the coordinator of the ethics subject the participants were enrolled in, having the interviewer as an final year law student reduced the likelihood

\footnotetext{
${ }^{52}$ W L Neuman Social Research Methods: Qualitative and Quantitative Approaches $3^{\text {rd }}$ ed (Boston, Allyn and Bacon, 1991) p. 328.

53 These were derived from Evans supra [n. 35], and from L De Groot-Van Leeuwen “Lawyers’ Moral Reasoning and Professional Conduct, in Practice and Education” in K Economides (ed), Ethical Challenges to Legal Education and Conduct (Oxford, Hart Publishing, 1998) p. 242.
} 
of the participants treating the interviews as a form of assessment. To this end the participants were made aware that their identity would not be disclosed to the principal researcher.

While acknowledging the strengths of the chosen interviewer it is important to canvass 'interviewer error.' The interviewer was not a professional social scientist and had not received advanced tertiary training in interview technique. To minimise this the interviewer was given direct training on interview technique and particularly on using opening-ended questioning. Further, during the interviewing stage the taped interviews were reviewed by the principal researcher and the interviewer and used as a basis to help the interviewer develop her interviewing skills. Another source of error might have arisen from the gender and age of the interviewer herself. It might be anticipated that as a young woman the interviewer might not have developed the same level of rapport with all the participants. However, reviewing the transcripts does not reveals any failures to 'connect' with any of the participants, and while different participants responded to different parts of the interview schedule in varying degrees of detail, not one interview shows the signs of a participant failing to engage with the questions and the themes of the interview.

All interviews were recorded and transcribed. Transcripts were codified according to categories that became evident through repeated analysis of the transcripts. The categories registered the conception of ethics that the participant was expressing. There appeared two master categories - Ethics as Something Else and Ethics as Morality. Within each master category several sub-categories emerged. These are set out in Table 2. 
Table 2: Codification Categories

\begin{tabular}{|l|l|}
\hline \multicolumn{1}{|c|}{ Ethics as Something Else } & \multicolumn{1}{c|}{ Ethics as Morality } \\
\hline Ethics as Social Justice & Ethics as Subjective Values \\
\hline Ethics as Law/ Unethical as Unlawful & Ethics as Being Nice/Honest \\
\hline Unethical as Commerce/Money/Wealth & Ethics as Family \\
\hline Ethics as Christianity/ Religion & Ethics not as Codes of Conduct \\
\hline
\end{tabular}

\section{Findings}

Findings Overview

The major finding of the research is that the participants had little conception of the ethical: That is the participants did not regard ethics as involving the public accountability to the Good for the practical values and judgments an individual makes in their daily life. Rather responses to direct enquires about ethics went in two directions. Ethics was either subsumed to another field of imperatives, like politics or law, or was treated as morality. As a consequence the participants had difficulty articulating responses to the specific ethical dilemmas. The participants' values and how the participants reached judgment were not clearly articulated. This underformed conception of ethics extended to the participants' perspective of their ethical formation with most conceiving ethical formation as an unthought process of accumulation with the private sphere of the family. 


\section{Ethics as Politics and Ethics as Law}

The first significant finding was that the participants did not recognise ethics as a distinct field for the thinking and evaluation of human action. Some participants saw ethics as synomous with formal striving for the Good (politics) or formal sanction for wrong action (law).

Several of the participants regarded being ethical as acting political. In particularly, they conceived ethical action as supporting or working for social justice causes or agencies. One participant made this conception of ethics particularly clear:

P: $\quad$...I think that's kind of why I got into law in the first place. Because I wanted to um, I probably have quite a naïve perspective of changing the world and doing, you know, being the ethical lawyer, work for Amnesty International and Greenpeace, that’s what I want to do. (Laughs) (Pause). ${ }^{54}$

Another responded justified describing her parents as ethical simply because "they've always supported charities and stuff.” ${ }^{55}$ In a similar vain one participant defined ethical lawyering as undertaking pro bono work. ${ }^{56}$

\footnotetext{
${ }^{54}$ Participant, M, Female, 20-22.

${ }^{55}$ Participant J, Female, 17-19.

${ }^{56}$ Participant E, Male, 17-19.
} 
The conception of ethics as social justice was linked to the perspective that money and corporate greed undermined ethical conduct:

P: I'm not really interested in that kind of aspect of the law, it's like working for a big corporation and stuff, you know lawyers working to make more money for somebody who already has a lot of money, and that's not something, I think that I'd, I could do. ${ }^{57}$

Another participant echoed similar thoughts, "things like that have given lawyers an unethical image ... that they're just after money and not um, not really caring about the client if they just get the money." 58 In fact sentiments that money leads to unethical conduct was a theme pursued by five of the fourteen participants. One participant suggested that the fantasy/horror film Devils Advocate were a young defence attorney falls for the corrupting power and wealth of a New York law firm, is indicative of the win and reap all the costs mentality of unethical lawyering. ${ }^{59}$

\footnotetext{
${ }^{57}$ Participant, M, Female, 20-22.

${ }^{58}$ Participant C, Female, 17-19.

${ }^{59}$ Participant I, Female, 17-19. Analysis of lawyers in this movie was undertaken by M Asimow "Bad Lawyers in the Movies” (2000) 24 Nova Law Review 533. But it must be added that not all participants regarded making money as antithetical to ethical conduct:
}

R: Um, ethical behaviour is pursuing um, happiness for yourself without hurting anyone else, um, I suppose an example of that would be pursuing a career um and following your goals, as far as, if you want to make some money or whatever, but doing so without um, stopping anyone else from getting where they want to go as well. Participant D, Male, 20-22. 
Seeing legal ethics as social justice or not involving the corporate pursuit of wealth involves seeing ethics as a political judgment concerned with questions of the Good for society, the profession, the environment or the world at large. Missing from this political vision is the accountability for the mundane, practical values and judgments made in everyday life. As such the participants are collapsing the ethical into the political. This transmuting the ethical into something else was common when participants where asked to give examples of unethical conduct. Many gave examples that were not unethical but illegal:

P: $\quad$ An example of that would be umm just recently I have been asked by a friend who's overseas to sell his car for him. Unethical behaviour on my part would be sell his car for $\$ 800$ and give him $\$ 600 .^{60}$

And:

P: $\quad$ An ethical dilemma, okay. Um, (pause), right, something like you've, someone has killed someone on their property, they came in, that robbed their house, or say a man killed another man because the guy killed his daughter or something like that. ${ }^{61}$

\footnotetext{
${ }^{60}$ Participant, K, Male, 23-25.

${ }^{61}$ Participant, L. Female, 17-19.
} 
Some participants were more direct, “...suppose crime obviously, murder and stuff

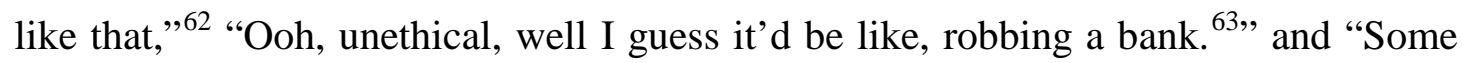
unethical behaviour, um, child pornography I think, um, is pretty much universally wrong." 64

Here the participants are conflating ethics was the formal public accountability of the criminal law. The participants seem to be indicating that ethics does not possess standards independent of law to support the evaluation and justification of specific human action. This lack of substance in ethics, that ethics does not possess values that can be talked about was another strong theme in the interviews.

\section{Ethics as Morality}

For many participants ethics elicited a subjective response. Ethics was treated as a question of morality, involving private accountability to the self. As one participant suggested, "Unethical behaviour? Um, (pause) well contradicting yourself or your own values. ${ }^{65}$ Another participant mirrored this perspective:

Unethical behaviour? (laughs) Umm, to me unethical behaviour is treating someone in a manner that goes against my morals and the way I myself would want to be treated. ${ }^{66}$

\footnotetext{
${ }^{62}$ Participant G, Male 17-19.

${ }^{63}$ Participant L, Female, 17-19.

${ }^{64}$ Participant E, Male, 17-19.

${ }^{65}$ Participant I, Female, 17-19.

${ }^{66}$ Participant K., Male 23-25.
} 
Another example:

Umm, (pause) hmm, I don't know, I guess I have quite strong principles, and if it goes against one of my principles then, you know, I think that would be unethical. ${ }^{67}$

However, in defining ethics as "my principles" this participant, like her colleagues did not disclose what exactly were those principles. In the words of participant $\mathrm{H}$ ethics involved “...like being really genuine, that's really important, I think, being genuine.”68 Several participants developed this subjective conception of ethics into a general theory of cultural relativism:

P: $\quad$ Of course, society plays a big role, because some cultures believe in killing their wives, and we don't. I just believe that going against your own grain and what you believe, what your parents have taught you is unethical. ${ }^{69}$

And:

I think in some situations it is ethical to have men dominating women, in some situations because it's part of their culture and in some ways

\footnotetext{
${ }^{67}$ Participant M, Female, 20-22.

${ }^{68}$ Participant H, Male, 17-19.

${ }^{69}$ Participant F, Male, 17-19.
} 
the preservation of the culture justifies some things that would certainly not be ethical in our own society. ${ }^{70}$

Further:

P: Um, I guess, growing up in Australia I guess, you have Australian values, they'd be a lot different to African or, I don’t know, something like that. Um, I probably have [unclear -'fairly good'] ethical values. $^{71}$

Tied up with this conception of ethics as subjective and culturally relative was the common emphasis that ethical judgments were intuitive:

P: I don’t think there's any like written requirement. But I guess that just like subconsciously requirements from yourself, like your own expectations as a lawyer. $^{72}$

What these various responses indicate is an understanding of ethics that regards the ethical as really morality. That ethics and ethical values are deeply personal, possibly intuitive and ultimately subjective, varying with the person and their cultural context. This conception of ethics as morality can be seen in the common response that ethics involves, "[e]verything that's right and wrong"73 while leaving what is right and what

\footnotetext{
${ }^{70}$ Participant E, Male, 17-19.

${ }^{71}$ Participant A, Male, 17-19.

${ }^{72}$ Participant C, Female, 17-19.

${ }^{73}$ Participant C, Female, 17-19.
} 
is wrong undefined and undisclosed. This lack of detail followed into how the participants justified their judgments to specific scenarios.

\section{Ethical (Non)-Decision Making}

In section two of the interview participants were asked to respond to three scenarios that suggested different ethical dilemmas. The first involved questions of loyalty to an unappealing client. The second involved the choice between the security of corporate practice or personal friendship. The third involved defending a known guilty client. On a whole the responses to these dilemmas was poor. Participants were inconsistent, did not reach conclusions, and where decisions were made the process of judgment remained undisclosed. The reigning impression from the participants is that ethical decisions are moral judgments for which the decision maker is not publicly accountable.

Many of the participants contradicted their express statements concerning ethical action when they responded to the ethical dilemmas. This is most obvious in the responses to the defending a known guilty client scenario. In response to the question “Can you describe an ethical dilemma that faces lawyers? How would you respond to that dilemma?" ten of the fourteen participants indicated that they would not be able to defend client they know is guilty. However, five of the ten indicated that they would represent the known guilty client in section two. A clear example of this conflict is participant $\mathrm{K}$ : 
I: Can you describe an ethical dilemma that faces lawyers and how would you respond to that dilemma?

P: $\quad$ Yes, in criminal law. Umm, for instance defending someone that you know to be guilty.

I: How would you respond in that situation?

P: I'd have to tell the, um, my client that they'd have to go and find someone else to work for them because I couldn’t do it. ${ }^{74}$

However, when asked to defend a known guilty client the participant's initial absolutism changes:

I: [reads question 10]

P: $\quad$ Defend my client. (Long Pause)

I: Do you have anything to add to that?

P: Umm, well, it's a sole parent, yes?

I: $\quad$ Yes.

P: $\quad$ Well I feel that, my client is not on charges for umm child abuse or anything like that, obviously a reasonable parent and therefore I assume that their going to be a lot better than the child becoming a ward of the state, umm so I would not want my client to risk going to gaol and the child ending up as an orphan, essentially. ${ }^{75}$

\footnotetext{
${ }^{74}$ Participant K, Male, 23-25.

${ }^{75}$ Participant K, Male, 23-25.
} 
Participant $\mathrm{H}$ also identified that defending a known guilty client as a significant ethical dilemma facing lawyers. His initial solution was "I'd end up doing is defending them half-heartedly.”76 However, once given a concrete situation this reluctance becomes active support: "Yeah, well, that guy deserves to have a, um, fair crack at getting um, getting away, acquitted." 77

For some participants the ethical challenge of what to do when faced with representing a known guilty client lead to indecision. One participant initially indicated, "if I had like every evidence that said that they did it and they want to plead not guilty, I would not defend them." ${ }^{78}$ However, when faced with the specifics of a dilemma this certainty turned into indecision:

P: $\quad$ Mm, okay, well, I guess um the two issues that come to mind are first of all, like, by the courts they did it, so therefore it would be unethical of you to defend them saying that they didn't do it, even though they deserve like a fair trial and everything. And the second thing is like the, like even though they did commit fraud the reasons behind it, um are good reasons, ethical reasons even though what they did was unethical, so um, yeah, so I don’t know what I'd do. ${ }^{79}$

\footnotetext{
${ }^{76}$ Participant H, Male, 17-19.

${ }^{77}$ Participant H, Male, 17-19.

${ }^{78}$ Participant C, Female, 17-19.

${ }^{79}$ Participant C, Female, 17-19.
} 
Failing to reach a decision was a common response to the other dilemmas. For example in response to the dilemma involving a choice between personal friendship and professional loyalty to an existing client, one participant indicated that:

P:...Um, I mean in the interests of the company I would stay with the transnational, in the interests I would help her out as best as I could, so, that depends how strongly the relationship, the friendship, is developed, if I believe there's a chance that she might be able to do, as well. That's basically what, I can't give you a definite answer, I'm sorry. ${ }^{80}$

Some participants failed to reach a decision by deferring decision-making to another party. When faced with the prospect of representing an unappealing client one participant reluctantly decides to give the client to someone else.

P: $\quad$ (long pause). Um, (long pause), I guess you'd um, speak to your client about it first. (Pause). Um, you could give the case to someone else who might be willing to take it. I probably wouldn’t be real keen on defending them. (Pause). Do I have to make a final decision?

I: $\quad$ Um, if you know what you'd do.

P: $\quad$ I probably wouldn't, I don't think.

I: Wouldn't keep going?

P: $\quad$ Yeah. I'd try and find another way out of it, basically.

I: Would you give that document to the other side?

\footnotetext{
${ }^{80}$ Participant F, Male, 17-19.
} 
P: No, I don't think so. I'd offer for someone else to defend him, but I might not give it to the other side. ${ }^{81}$

Another participant showed similar indecision in response to the dilemma involving defending a known guilty client. At the abstract level the participant 'solved' the dilemma by absenting herself:

I: How would you respond if you were in that situation [defending a known guilty client]?

P: Being a lawyer in that situation? I'm not going to be in that situation. Don't want to do that at all. ${ }^{82}$

However, when asked to respond to the case scenario the participant changed from absence to personal judgment.

I: ...the single parent ripped off the government at the end of the day. So I don't know, this is challenging. This is making my brain work! I think you have to think of what would be worse, and I think it would be worse for the children not to have a parent for four years, so I think I'd probably, this is so unethical! I think I'd probably try to get the mother off. But I would say to her, I would make sure she knew that I felt what she did was still wrong, and I'd probably say to her that if

\footnotetext{
${ }^{81}$ Participant A, Male, 17-19.

${ }^{82}$ Participant J, Female, 17-19.
} 
she ever did it again then I'd dob her in or something, so I'd definitely still let her know that I wasn’t happy about it... ${ }^{83}$

This recourse to judgment about the deserving or undeserving nature of others was a strong characteristic of most participants. When presented with the gatekeeper decision of who they would represent, the participants based their decision on a subjective evaluation of the client's attributes. The following extract provides a clear example of this, in the participant's condensation of justice and professional integrity into personal morality:

P: Um, yeah, um, I think, I think that professional integrity is probably influenced by your personal beliefs and values, um, well the extent to which they comply with each other, well, yeah it does have influence because I wouldn’t go through with, you know, putting children in the hands of an unsuitable parent. Um, I think that's morally wrong, or ethically wrong, and you know, if you're representing justice, you know you're the person or the lawyer, there's no way you should, that should happen. ${ }^{84}$

Another participant ultimately posits their personal morality as the illuminating values for justice and professional integrity: "He broke the law but punishing him for it is

\footnotetext{
${ }^{83}$ Participant J, Female, 17-19.

${ }^{84}$ Participant I, Female, 17-19.
} 
unjust. So professional integrity, you've got to, you've got to decide for yourself what is just, so, professional integrity definitely." ${ }^{85}$

However, most participants were not as transparent and reflective. Many just made confident judgments based solely on personal assessment of the deserving or undeserving nature of the client:

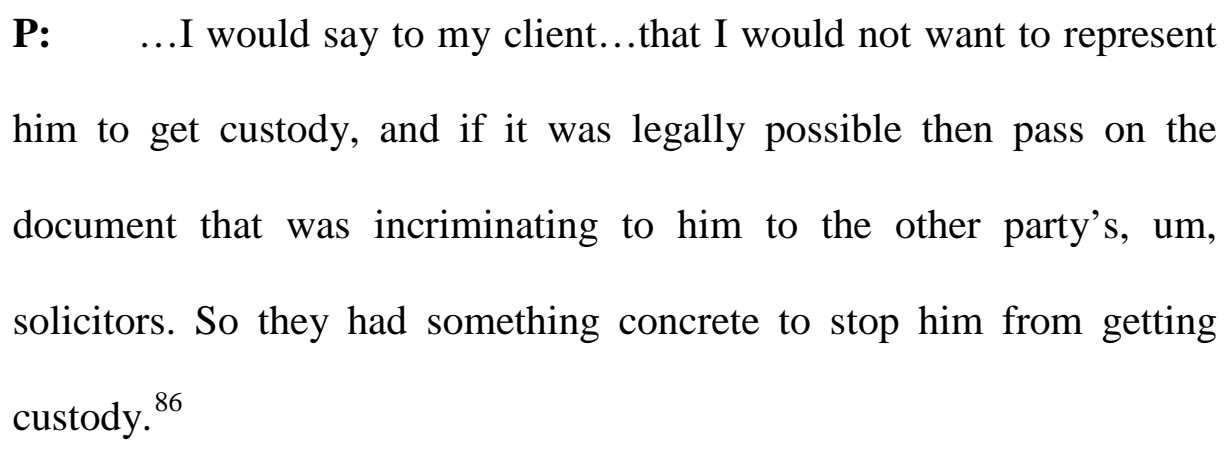

And when faced with the prospect of representing an appealing known guilty client the same participant indicated:

P: $\quad$... As long as I thought that he really didn’t deserve a gaol term, the not guilty plea would be what I would go for. ${ }^{87}$

Other participants made similar responses to that scenario:

\footnotetext{
${ }^{85}$ Participant F, Male, 17-19.

${ }^{86}$ Participant D, Male, 20-22.

${ }^{87}$ Participant D, Male, 20-22.
} 
P: $\quad$ Oh, I reckon I'd give it a go. Represent him really well. (long pause). ${ }^{88}$

The subjective nature of these decisions was emphasised by the reluctance of participants to reveal either the values on which the decision was based or the process through which the judgment was reached:

I: So you'd keep working for the client?

P: I'd keep working for the client so that I could throw the case and make sure they didn't get the children.

I: $\quad$ And can I just ask how these factors affected or influenced your decision: client confidentiality?

P: $\quad$ Uh, I'd still maintain that.

I: Professional integrity? Is that, how much did that influence?

P: What's professional integrity?

I: [interviewer defines professional integrity]

P: $\quad$ Uh, no I wouldn't act in favour of that.

I: Civic duty, so the child's protection?

P: Yeah, definitely.

I: And business efficacy, you're firm's profits.

P: No, I wouldn't act for that. ${ }^{89}$

\footnotetext{
${ }^{88}$ Participant L, Female, 17-19.

${ }^{89}$ Participant B, Female, 17-19.
} 
In this extract the participant's process of judgment remains opaque despite the interviewers questions. The participant's decision, that she would continue to work for an unappealing client just to ensure that the client loses, is confidently presented as uncontroversial and not requiring explanation or justification. Even after the interviewer explains professional integrity the values and processes informing the decision remain hidden and private; all the participant can say is she "wouldn't act in favour of that." This is not to suggest that this participant is valueless and opportunistically engaging with the world. Clearly, the issue in the scenario, that there was evidence that the client would not be a suitable parent, was of overarching concern for the participant. Excavation can probably identify the participant's ethical calculus; security and wellbeing of children are of absolute importance. Any other values in the scenario (client loyalty, professional integrity) are secondary; therefore, care for children mandates not just negative acts (such as withdrawing representation), but positive acts (ensuring client does not get the children). ${ }^{90}$

The significance is that identification of the ethical decision making process had to be excavated and reconstructed on the basis of an estimate; that the participant did not regarded it as something to be talked about or justified. Instead, highly significant judgments about how lawyers should act, whom they should serve and who can

9010 of the participants appeared to follow a similar ethical process to Participant B, indicating that they would either pass information to the ex-partner’s lawyers, pass the information to relevant government authorities or withdraw representation. Like B for these participants the reason seemed to be because "kids are something you can’t really stuff around with at all [Participant G, Male 17-19]. It seems that the value of families is significantly high for Australian law students. Evans and Palermo similarly found that students preferred family values, in either to protect members of their own family or protect children generally. Evans and Palermo supra [n. 37], pp. 111-112, 121. 
access justice is located within the morality of the subjective self and as such locked behind the private firewall of the public/private divide. This private understanding of ethics extends to the participants' conception of ethical formation.

\section{Ethical Formation}

In section three of the interview the participants were asked to consider the origins of their ethical values. Again the participants conceived ethical development as a private matter that is self-evident and not requiring discussion. Ten of the fourteen participants conceived their ethical development as "just accumulated"91 or "no big event...created all those ideas in me. I think it’s just more been over time.”92 Nine of the participants saw this ethical accumulation as occurring within the domestic context of their family. ${ }^{93}$

Further, most participants considered that their parents would probably respond to the dilemma scenarios in section two in a similar manner to themselves. Finally, three regarded their schooling in large established religious schools as a complementary extension of their accumulative family values:

P: $\quad$...it's firstly, it was my parents that taught me what's right and wrong.... and then secondly, I feel I got the rest from school. Umm and having done 12 years of Catholic schooling, umm you know I feel

\footnotetext{
${ }^{91}$ Participant A, Male, 17-19.

${ }^{92}$ Participant D, Male, 20-22.

${ }^{93}$ Participant L, Female, 17-19 defined the ethical as "Like, ooh, loving your parents or mm, heaps of stuff, like doing your homework (laughs).”
} 
that's I've turned out all right and all of that, so yeah, complete my background and my parents, they dictate my ethical values. ${ }^{94}$

The participants indicate that ethical development just happens, and when it does happen it occurs with the private domestic environment and the privileged site of mainstream Christian education. One participant makes these points explicitly:

P: I think because I come from a reasonably well off family, um, I haven't needed to uh, rob or steal or do any criminal offences, there's been no need for it...

I: So you think it was quite, your background was quite influential then?

P: Um, influential yeah. Um, think, um religion has influence in being Christian. Um, at least the principles, you know the 10 Commandments and the gist of it, love one another, um, that'd have, you know because you have some responsibility to try and uphold the principles where you can. Um, I'm not sure what else. ${ }^{95}$

Therefore, the participants' conception of ethical development reinforces the private, undisclosed and subjective understanding of ethics as morality utilised by the participants in responding to the ethical dilemmas.

\footnotetext{
${ }^{94}$ Participant K, Male, 23-25.

${ }^{95}$ Participant E, Male 17-19.
} 
In summary, the central finding of this study is that the participants have no clear conception of ethics. Ethics is subsumed to law, politics or morality. Further, this absence of the ethical means the participants' approaches to ethical decision-making involves contractions, avoidance of decisions and subjective closed judgment according to undisclosed private values and undisclosed processes. Finally, this lack of ethical awareness is manifest in the participants' regarding ethical development as just accumulating in the private sphere of family.

\section{Analysis: Teaching the Ethical}

The findings present significant challenges to the project of ethical legal education. The findings suggest that the conception of ethics that informs the call for legal ethics, that there is a field for thinking about human action that is concerned with the public accountability to the Good for the practical values and judgments an individual makes in their daily life, is not shared by students. Ethics needs to be seen as distinct from law, politics, and especially morality. Fortunately, the research does suggest that the participants possessed a 'proto-ethical' handle that might be built upon to delineate the ethical to students. The research also suggests the significance of experiential learning in appreciation of the ethical.

For teachers involved in ethical legal education these findings could be cause for serious disillusionment. As a cohort the participants did not consider that their values and judgments could or should be open to public accountability. The participants came across as extreme positivists - that provided an action was legal any values or judgments were subjective and private. They generally did not feel that they had to 
justify or explain decisions that they made. Instead, they were quite explicit that accountability for values and judgments was to the private and undisclosed self.

This finding, that the participants were textbook positivists, should not come as a surprise. Others have made similar observations about contemporary tertiary students. ${ }^{96}$ Indeed, a significant portion of the resistance experienced by Parker in teaching a final year ethics subject stemmed from her students conflating ethics with morality and then objecting to the perceived attempt by Parker and her co-workers to talk, teach and examine values and judgments. ${ }^{97}$

The lesson for the project of ethical legal education in this finding is that antecedent to the development of the ethical lawyer is the desperate need to address the inherent positivism that law students are bringing to law school. In short to be the ethical lawyer called for by many in the profession as the solution to the malaise of practice, students must be made aware of the ethical as a legitimate realm for the discussion and evaluation of human action. This seemingly is no easy task. Parker suggests that the resistance of students to ethics education stemmed from their exposure to the law school environment. The finding from this research suggests that the failure to see the ethical as the ethical lies much earlier in a student's intellectual development. The spectre of hopelessness seems to loom large for the project of ethical legal education and the development of an ethical profession; is it that students and contemporary lawyers reflect a cultural context that is so strongly individualistic, privileges the private and is generally antithetical to the public accountability of the ethical? It is

\footnotetext{
${ }^{96}$ R Momeyer “Teaching Ethics to Student Relativists” (1995) 18 Teaching Philosophy 301.

${ }^{97}$ Parker supra [n. 36], pp. 175-205.
} 
tempting to lambast the participants as the selfish, self-absorbed, value nihilist progeny of a particularly conservative epoch, ${ }^{98}$ and at times the participants openly exhibited conservatism and selfishness. Two participants disclosed that they regarded their parents as ethical because they conformed to classic gender norms:

P: $\quad$...my dad is full of enjoyment of life, you know, he eats, drinks and be's merry and you know, just that having a good time. And whereas my mum is much more sensitive, and you know she, and she’s also very clever as well, so. ${ }^{99}$

And:

P: Well, my Mum, with her family, good family ethics, and she puts family first, a lot of the time, in front her. And that's not always a good thing, um, as well, but it's pretty admirable. ${ }^{100}$

\footnotetext{
${ }^{98} 65 \%$ of the students were born after 1982. It is possible to cast them as the children of Fukuyama's "end of history." (F Fukuyama The End of History and the Last Man (London, Penguin, 1992) They were in middle primary school during the fall of the Soviet Union and young teenagers when the current incumbent and strongly conservative Howard Coalition government won office in 1996. On the conservatism of the Howard government P Mendes "From Keynes to Hayek: The Social Welfare Philosophy of the Liberal Party of Australia, 1983 - 1997” (1998) 15 Policy, Organisation and Society 65.

${ }^{99}$ Participant M, Female, 20-22.

${ }^{100}$ Participant I, Female, 17-19.
} 
Several others regarded ethics as the necessary drive to perform well in corporate practice, “...you wouldn’t change sides too many times in your career. You're not really being a very good lawyer, you're not being loyal to your job.” ${ }^{101}$ And:

P: $\quad$ there are lots of things that are ethical, but um, all, an example would be I suppose, uh, in the sense of law, like if a client came to you just giving it your best and if it means going over past 5 o'clock, you know, on your working day, well then doing that. ${ }^{102}$

However, the participants do not fit the description as conservative, greedy selfmaximisers who strongly object to talk about values. While the interviews do revel that the participants had no clear conception of the ethical as a distinct realm for the discussion and evaluation of human action, they do disclose that the participants were concerned with, in the words of participant G “just being a good bloke, I suppose. Helping out other people. Trying to get along with anyone and not being selfish and all that."103

This conceiving of ethics as being a "good bloke" suggests a proto-ethical understanding. Underlying the perspective of being a "good bloke”, of helping others, of getting along with others, of "not being selfish and all that", seems to be a concern with the effect of values and judgments on others. This introduction of others into the conception of ethics provides a direct challenge to ethics as morality. To contemplate

\footnotetext{
${ }^{101}$ Participant E, Male, 17-19.

${ }^{102}$ Participant C, Female, 17-19.

${ }^{103}$ Participant G, Male, 17-19.
} 
that ones values and judgments impact and effect, not some insubstantial concept of the public or society, but register on the concrete lives of others, opens the way for true appreciation of the ethical. ${ }^{104}$ To recognise that ones actions must be made to account to the other is to introduce the idea that values and judgments can no-longer be the preserve of the self, but must be explained and justified to the Good.

This realisation indicates that an approach to teaching ethics might be more successful if the relationship between the self and the other is prioritised. ${ }^{105}$ This resonates with the conclusion from Groot-van Leeuween survey of law students in the Netherlands that:

\footnotetext{
"In teaching legal ethics, therefore, the ethics of care need to be taught too. Students should be supported to articulate and objectify their (nongendered) ethics of care intuitions, paying attention to those ethics' vision of the self the world. ${ }^{106}$
}

Simply put the participants did possess a degree of empathy and were concerned with how the actions of the self affected others. However, this empathic orientation was only a suggestion, a proto-ethical conception. ${ }^{107}$ At times this proto-ethics was

\footnotetext{
${ }^{104}$ Webb supra [n 12] p. 140.

${ }^{105}$ B Martin “Place: An Ethic of Cultural Difference and Location” (2000) 32 Educational Philosophy and Theory 81.

${ }^{106}$ De Groot-Van Leeuwen supra [n. 53], p. 250.

${ }^{107}$ In calling this phenomenological relation with other a proto-ethical moment I am following elements of Emmanuel Levinas' analysis that the naked absolute responsibility for the Other precedes and gives meaning to human life. Therefore, what we have defined as the classical conception of the
} 
manifested only superficially: “Helping people that are in need. I don’t know, things like throwing a few coins in a busker’s guitar case or whatever.”"108

And:

I: $\quad$ Can you give me an example of something that's ethical?

P: $\quad$ Oh, like um, helping a lady cross the road? ${ }^{109}$

However, several participants were clearer in expressing this proto-ethical conception; “[ethics involves] um, honestly having the best interests of the other person at heart.”110 For example one participant indicated that ethical conduct:

P: Um, would be acting to please other people I would think. (long pause). An example of that is just thinking of others before you act. (long pause). ${ }^{111}$

ethical is framed and made urgent by the proto-ethical encounter with the other. E Levinas "Ethics as First Philosophy” (trans S Hand and M Temple) in S Hand (ed), The Levinas Reader Oxford, Blackwell, 1989) p. 83, C Douzinas “Justice, Judgement and the Ethics of Alterity” K Economides (ed), Ethical Challenges to Legal Education and Conduct (Oxford, Hart Publishing, 1998) and Webb supra [n. 12] pp. 130-151. On Levinas in legal thought generally see C Douzinas and R Warrington Justice Miscarried: Ethics, Aesthetics and the Law (Hemel Hempstead, Harvester Wheatshealf, 1994).

${ }^{108}$ Participant J, Female, 17-19.

${ }^{109}$ Participant A, Male, 17-19.

${ }^{110}$ Participant H, Male, 17-19.

${ }^{111}$ Participant B, Female, 17-19. 
Unfortunately, these glimpse of the ethical, through a proto-ethical empathy for others, were brief. Express statements that ethics is about care for others was generally left unsubstantiated and when pushed tended to dissolve. This can be seen in the following extract. Having confidently answered the question "What do you understand as ethical behaviour," the participant falls back onto intuitive and the private realm of morality:

P: (pause), refusing to lie, cheat, screw somebody for your own personal gain, being honest, being truthful, um, what do I think is being unethical. I mean, just immoral, being immoral, behaving in a way that is just not the right way. Right determining right, okay. Good question. I know, what comes from within, I can't give you, I can’t give you an outline ${ }^{112}$

Nevertheless, the research does suggest that focusing on the relation with the other might be a way of developing an appreciation of the ethical in students. However, an empathy approach to ethics depends on knowledge of the other; of the diverse, different lives that others live. As such empathy seems to be predicated on lived experience and reflection on the different lives that people live. However, most of the participants had lived a sheltered life. As a cohort the participants were young and still living with their parents in affluent suburbs. ${ }^{113}$ As observed most saw their ethical

\footnotetext{
112 Participant F, Male, 17-19.

${ }^{113}$ Although the University of Notre Dame Australia was a private, Catholic law school the background of the participants seems remarkably consistent to the national mean for Australian law students. Evans and Palermo sample of the national graduating class of 2001 found that most final year law students were young (60\% 18-25) and residing in high socio-economic areas. Evans and Palermo supra [n. 37]
} 
development occurring as a process of osmosis from their family. Only two participants indicated that experiencing marriage breakdown had influenced their ethical outlook. It appears that for the majority of participants no significant event had intruded on their sheltered context. It is therefore not surprising that the older participant, participant $\mathrm{N}$ differed significantly from the other participants. $\mathrm{N}$ was prepared to explain both the values and judgments that he made. Further, $\mathrm{N}$ was able to draw upon personal experience to help resolve specific ethical dilemmas. For example in response to the scenario that examined conflict between a friend and professional loyalty to an existing client, $\mathrm{N}$ was able to draw on concrete relevant personal experience:

But I have actually learned sometimes that friendships can be really dangerous in the corporate world...if you're doing it to help a friend or to do whatever, sometimes it’s just, for whatever reason, I’ve seen it a lot, it can bite both parties, it can turn around and bite both of them on the behind.

This is not to suggest that $\mathrm{N}$ was more ethical then the other participants, but that N's life experience seemed to make him more open to a need to publicly account for values and judgments to some conception of the Good.

pp. 108-109. Evans and Palermo’s finding is consistent with an unpublished paper by Goldring that surveyed the backgrounds of law students in Victoria in 1996. Goldring found that the vast majority of students entering legal education were from privileged middle class backgrounds - cited in Goldsmith and Powles supra [n. 21], p. 123. 
This suggests a hurdle for an empathy driven approach to teaching legal ethics: As it is possible that most law students lack the life experience to appreciate effects on the other. However, the research does suggest how the empathy of law students could be developed. As set out earlier a key component of the University of Notre Dames Australia commitment to ethical education was a mandatory voluntary service program that placed students within community-based agencies providing services to the poor and disadvantaged. Several of the participants reflected that this exposure to the dramatically different lives of others had developed their empathy. For example:

P: $\quad$...I've done some community service, with the soup patrol [the Red Cross Soup Van that provided soup and bread to homeless people around Fremantle]...you can see the lights of the cafes where you hang out with your friends or whatever um, from the back of the van, and it's just amazing, you wouldn't look down those alleys or wherever they stop, down those roads, and it's really close in proximity, but you wouldn't look at that side of life. And, just if you think that that could be you, if you came from a different background, you could be the guy getting the soup from the van. ${ }^{114}$

In being faced with radically different life experiences within the very neighbourhood of the University participant $\mathrm{E}$ is displaying the hallmarks of empathetic reflection. It is interesting that participant $\mathrm{E}$ was one of the few participants who made the link between lawyering and justice.

\footnotetext{
${ }^{114}$ Participant E, Male, 17-19.
} 
P: $\quad$...Um, you could argue that someone should do a lot more than that and spend a lot more time doing pro bono work.

I: Why is that?

P: $\quad$ Because there are injustices in society and the whole idea of lawyers is to make justice and it's supposed to be a justice system, and if there's an injustice in it then it's not a very good system. ${ }^{115}$

In this respect the findings mirrors the common claim by proponents of CLE that exposure to experiential learning at law school might produce a greater justice orientation in graduates. ${ }^{116}$ However, this reflection on experience leading to what Evans' calls justice values does not necessarily reflect an awareness of the ethical. Participant E's talk of injustice is political, not ethical, in that he as an individual is absent from the conception. When it came to defining the ethical participant $\mathrm{E}$ articulated the subjective ethics as morality in common with his colleagues:

P: Um, unethical behaviour is, um, I think you obviously first have to define um, what ethical is, and that's very different because different people have got different ideas, but um, I don’t think mine has any

\footnotetext{
${ }^{115}$ Participant E, Male, 17-19.

${ }^{116}$ Most recently by Evans supra [n. 35], pp. 242-243. Also S Maresh “The Impact of Clinical Legal Education on Decisions of Law Students to Practice Public Interest Law” in J Cooper and L Trubek (eds), Educating for Justice: Social Values and Legal Education (Aldershot, Ashgate Dartmouth, 1997) pp. 154-166 and I Styles and A Zariski “Law Clinics and the Promotion of Public Interest Lawyering” 19 Law in Context 65. For an advocate of non-CLE experiential learning through roll-playing and simulation see J Moliterno ‘Professional Preparedness: A Comparative Study of Law Graduates’ Perceived Readiness for Professional Ethical Issues” (1995) 58 Law and Contemporary Problems 259.
} 
strong principles uh, that uh, have to be adhered to, no matter what, like universal truth kind of thing. ${ }^{117}$

So while experiential learning strategies might provide the experience of the other to begin an empathic appreciation of the ethical, how the process of reflection is organised and managed is important. Participant E perhaps demonstrates the difficulty involved in making students aware of the ethical for while E's experience seemingly had registered politically in his concern with the Good, he had yet to place himself and his personal values and judgments within the context of accountability to the Good.

In summary the key finding that law students do not have a clear conception of the ethical does not suggest a degree of hopelessness for the project of ethical legal education. It is possible to discern a proto-ethics in the concern of the participants to be nice. This empathy for the other suggests a way for legal educators to focus on the ethical as the ethical. However, this research also shows that empathy was related to life experience and a majority of participants had lived a particularly sheltered existence. While experiential learning strategies might expose students to the other and allow for appreciation of the ethical, careful management would be required for such experiences to lead to an awareness of the ethical.

\section{Conclusion}

${ }^{117}$ Participant E, Male, 17-19. 
This research was based on the perspective that underpinning the widespread calls for a more ethical legal profession is a particularly strong conception of ethics as dealing with the public accountability to the Good for the practical values and judgments an individual makes in their daily life. While rarely made explicit within the calls for an ethical legal profession, this conception of ethics, which reflects classical definitions of the ethical, is implicit within the instrumental desire of advocates to change the culture or mindset of legal practice.

Having delineated the ethical, and in the process orientated the ethical in relation to the moral, the legal and the political, this research attempted to construct a baseline conception of ethics for students beginning their legal education. The primary finding was that students did not comprehend that accountability for the Good of values and judgements could be made public to standards that were not legal. Instead, as a cohort the participants regarded ethics as the private, subjective realm of morality.

This implication for the project of ethical legal education of this baseline conception of ethics is significant. It suggests that before law teachers can talk and evaluate values and judgments, the student must be made aware of the ethical as a distinct and legitimate site for the discussion and evaluation of human action. The research suggests that one way this could be achieved is by focusing on the proto-ethical empathy to the other that the students seem to possess. However, the research also seemed to indicate that the level of empathy was related to life experience. But this was problematic due to the fact that most students entering legal education are teenage school leavers from sheltered backgrounds. The research suggests that 
experiential learning, provided it is managed carefully, might facilitate empathic awareness and through empathy appreciation of the ethical as the ethical. 


\section{Appendix}

\section{LEGAL ETHICS AND SERVICE LEARNING}

Thank-you for your time. Before we start I want to make it very clear that your participation in this research and the answers you give will have no relation to your marks for ET100.

This research is part of an ongoing nation-wide study into values and ethics of law students. It also aims for us to assess the benefits of using service learning strategies in teaching legal ethics.

Further, all precautions will be maintained to ensure your anonymity. While staff involved in ET100 will examine the transcript of this interview they will have no way of distinguishing your identity. For recording purposes we will tape our discussion and I will take notes.

There are not right answers to any of these questions. The whole purpose of the research is for us and other legal educators to better understand where first year law students are coming from and what they experience and learn from service learning.

If you are happy to continue please complete the consent form. The consent form contains further information about the project.

This interview will take approximately 30 minutes. We will undertake another interview after the final marks for ET100 are finalised in winter. This later interview will focus on course in more detail.

This interview is divided into four sections.

Section 1 involves us talking about what you consider "ethical behaviour and professional conduct."

Section 2 involves you responding to several scenarios.

Section 3 ask you to reflect on the origins of your understanding of ethics.

Section 4 asks demographic questions of you.

\section{SECTION 1 ETHICAL BEHAVIOUR AND PROFESSIONAL CONDUCT}

Question 1: Why did you enrol in law school?

Question 2: Who do you admire as an ethical person? Why?

Question 3: What do you understand as “unethical behaviour?” Can you give an example?

Question 4: What do you understand as “ethical behaviour?” Can you give an example?

Question 5: Do you think ethics are irrelevant to lawyers? Why/ Why not?

Question 6: What do you think are some (if any) of the ethical requirements on lawyers?

Question 7: Can you describe an ethical dilemma that faces lawyers? How would you respond to that dilemma?

\section{SECTION 2 ETHICAL BEHAVIOUR AND PROFESSIONAL CONDUCT}

Question 8 
You are a lawyer representing a party in a messy divorce hearing. Both parents are claiming that they should receive custody of their two children. Your client has just dropped off a large quantity of formal papers. Accidentally included in those papers is a document that seriously questions your clients ability to adequately care for the children. After reading this document you have no doubt that the other party would make a far more suitable parent than your client. The other side does not know of the document or its contents. What do you do?

Can I ask you how these factors affected or influenced your decision?

Client Confidentiality

Professional Integrity

Civic Duty(child protection)

Business Efficacy (Firm’s Profit)

Question 9

You are a corporate lawyer working in private practice. One of your clients is a large transnational company. Over the past 5 years you have worked with the Australia director of the company on various issues. You have a good relationship with the director and have become good friends. The Director having left the company has established her own company competing directly with her old employer. She has asked you to do legal work for her fledging company. Your firm can only work for one or the other. Remaining with the transnational company would be significantly more financially rewarding. What do you do?

Can I ask you how these factors affected or influenced your decision?

Business Efficacy (Firm’s Profit)

Personal Integrity

Friendship Loyalty

Personal Happiness

Question 10

You are defending a single parent who has been charged with social security fraud. The client admits to you that they did the fraud to pay for dental work for their oldest child. The evidence against your client is not strong. If you go to trial and plead not guilty they have a good chance of being acquitted. However, if he is found guilty he will probably get a goal term. What do you do?

Can I ask you how these factors affected or influenced your decision?

Personal Integrity

Professional Integrity

Client's Interests

Access to Justice

\section{SECTION 3 YOUR UNDERSTANDING OF ETHICS}

\section{Question 11}

How has your background influenced/shaped your responses to ethical issues?

Question 12

Would you share your response with your parents? Would you differ? Can you give an example?

Question 13

Has there been any single formative experience that has shaped your responses to ethical dilemmas?

SECTION 4 Demographics 
This section is to ensure that we interview all different types of people. It is also a requirement of the Commonwealth funding. You do not have to answer these questions. It will help us if you did.

Question 13: SEX:

Question 14: AGE

17-19, 20-22, 23-25, 26-30, 31-35, 36-40, 41-50 50+

Question 15: What is the suburb or postcode where you live?

Question 16: Do you reside with your parents (YES/NO)?

Question 17: If NO to Question 16 What is the suburb or postcode where your parents live when you where growing up?

Question 18: Were you born in Australia? If "NO” where were you born? If "NO” How long have you been in Australia?

Question 19: For the purposes of the follow up interview. When would you be able to do an interview over winter term?

Thank-you for your time today 